\title{
Correlation of HER 2/neu Gene Amplification with Immunohistochemistry and Other Prognostic Factors in Breast Carcinoma
}

\author{
Meme Karsinomlarında HER-2/neu Gen Amplifikasyonu ile \\ İmmunohistokimya ve Diğer Prognostik Faktörlerin Karşılaştırılması
}

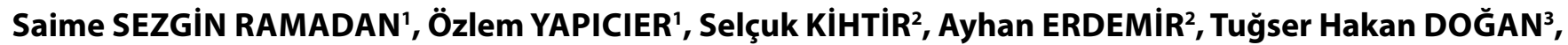
İsmail Necdet Hakkı ÜSKENT ${ }^{4}$, Haluk ONAT ${ }^{4}$, Metin ÇAKMAKÇı ${ }^{2}$
\end{abstract}

Departments of ${ }^{1}$ Pathology, ${ }^{2}$ General Surgery, ${ }^{3}$ Radiology and ${ }^{4}$ Medical Oncology, Anadolu Medical Center, KOCAELI, TURKEY

\begin{abstract}
The purpose of this study was to determine relationship between HER-2/neu status and estrogen receptor, progesterone receptor, grade and age by comparing fluorescence in situ hybridization and immunohistochemistry. One hundred invasive breast carcinomas were reviewed and fluorescence in situ hybridization analysis was performed in all cases. Immunohistochemical scores showed a perfect concordance with fluorescence in situ hybridization amplification ratios $(\mathrm{p}<0.0001)$. The results indicated a significant correlation between HER-2/neu and grade, but an inverse relationship between HER-2/neu and hormone receptors. In women aged $\leq 45$ years, an inverse relationship between HER-2/neu and progesterone receptor was found and no association was noted between HER-2/neu and other factors. In women aged $>45$ years, the results indicated a significant correlation between HER-2/neu and grade, and there was an inverse relationship between HER-2/neu and hormone receptors.
\end{abstract}

Key Words: Breast, Carcinoma, HER-2/neu, Immunohistochemistry, Fluorescent in situ hybridization
ÖZ

$\mathrm{Bu}$ çalışmanın amacı, invaziv meme karsinomlarında HER-2/neu statüsünün immunohistokimyasal ve floresan in situ hibridizasyon yöntemi ile karşılaştırılarak, östrojen reseptörü, progesteron reseptörü, derece ve yaş gibi prognostik parametrelerle ilişkisinin değerlendirilmesidir. Yüz invaziv meme karsinomu tekrar değerlendirilmiştir ve tüm olgulara floresan in situ hibridizasyon uygulanmıştır. İmmünohistokimya skorları ile floresan in situ hibridizasyon amplifikasyon sonuçları arasında yüksek uyum saptanmıştır $(\mathrm{p}<0.0001)$. HER-2/neu statüsü ve derece arasında doğru orantı, hormon reseptörleri ile ters orantı bulunmuştur. 45 yaş ve altı kadınlarda progesteron reseptörü ve HER-2/neu amplifikasyonu arasında ters orantı saptanırken, diğer prognostik faktörler arasında herhangi bir ilişki saptanmamıştır. 45 yaş üstü kadınlarda ise, HER-2/ neu amplifikasyonu ile hormon reseptörleri arasında ters ve derece arasında doğru orantı bulunmuştur.

Anahtar Sözcükler: Meme, Karsinom, HER-2/neu, İmmunohistokimyasal, Floresan in situ hibridizasyon

\section{INTRODUCTION}

Breast cancer is the most common life-threatening malignant neoplasm in women. Clinical outcome is affected by a number of established prognostic factors, including age, tumour grade, estrogen receptor (ER) and progesterone receptor (PR) status (1-4). One of the most common genetic alterations associated with human breast cancer is the HER-2/neu amplification. Molecular alterations in breast cancer are being incorporated into the development of new treatment strategies.
The HER-2/neu (C-erbB-2) gene is localised to chromosome $17 \mathrm{q}$ and encodes a transmembrane tyrosine kinase receptor protein that is a member of the epidermal growth factor receptor family. Slamon et. al. were the first authors to find a strong and highly statistically significant correlation between the degree of gene amplification and both time to disease relapse and survival (5). Previous studies have shown the prognostic and predictive value of HER-2/neu overexpression in node positive breast cancer $(6,7,8)$ and for metastatic disease $(9,10)$. 
Trastuzumab is a humanized antibody against the external domain of HER-2/ neu that presents antitumoral activity (11). Trastuzumab improves response rates, time to progression and even survival when used alone or added to chemotherapy in metastatic breast cancer (12). It is also active as a single agent and reduces the risk of recurrence and mortality in patients with early-stage breast cancer (13-15). The interesting point of such a specific treatment is that only those tumors that overexpress HER-2/neu benefit from such therapy. The determination of HER-2/ neu in breast cancer is very important as it has significant benefits and some side effects like cardiotoxicity (16). Overexpression of HER-2/neu is most commonly caused by amplification of the HER-2/neu gene, which results in increased HER-2/neu mRNA levels and concomitant overexpression of the HER-2/neu receptor on the tumor cell surface. There is no "gold standard" for HER-2/neu testing but immunohistochemistry (IHC) and fluorescence in situ hybridization (FISH) are the most commonly used methods. In addition, chromogenic in situ hybridization and silver in situ hybridization has recently been validated as alternatives to FISH.

Early studies suggested that as many as $30 \%$ of breast cancers have HER-2/neu overexpression (17). However, recent studies showed lower results around 20\% (18-20) The American Society of Clinical Oncology (ASCO) and the College of American Pathologists (CAP) convened an expert panel and recommended a new HER-2/neu testing guideline in 2007 to decrease discordant results (12).

HER-2/neu overexpression has been correlated with several poor prognostic paramaters. They are more likely to be hormone-receptor negative and have higher tumour grade $(3,7,21)$. The inverse association between HER-2/neu and hormone receptors has been linked with the fact that estrogens suppress HER-2/neu through the ER (22). One recent report showed that this inverse association differs in different age groups (23). Tumor grade, as an important predictor for HER-2/neu overexpression shows an association with hormone receptor expression that differs between young and older women and this may be reflected with an age-related association between hormone receptors and HER-2/neu (24-25).

Taken together, the aim of our study was to better understand the relationship between HER-2/neu status and other prognostic factors like age, tumour grade, ER and PR receptor status by comparing the results of immunohistochemistry and FISH in invasive female breast carcinomas at our institution.

\section{MATERIAL and METHODS}

\section{Tissue Samples}

The study material comprised 100 cases of invasive mammary carcinoma diagnosed at or referred to Anadolu Health Center, Kocaeli, between February 2005 and June 2008. The cases were included in the study only if paraffin blocks were available for FISH. Some of the cases which were sent to our Department for second look had only $\mathrm{H} \& \mathrm{E}$ slides and were excluded from the study. FISH was applied to all cases with IHC scores 0 to $3+$. Tumours were graded according to the Bloom Richardson grading system. Among the 100 cases were 86 ductal carcinomas, 3 tubular carcinomas, 3 mucinous, 3 mixed, 2 medullary, 1 papillary, 1 lobular and 1 basal-like carcinoma. Only medullary carcinomas were not graded according to the American Joint Committee on Cancer 2002 (26).

\section{Immunohistochemistry}

From all cases a set of 4 micrometer-thick paraffin sections were cut and stained for ER (Novocastra-Clone 6 F 11), PR (Neomarkers- Clone SP 2) and HER-2/neu (NovocastraClone 10 A 7) antibodies by using microwave for antigen retrieval. The staining for ER and PR was classified as positive if more than $10 \%$ of the tumor cells exhibited nuclear staining. The HER-2/neu stained slides were scored on a scale of 0 to $3+$ according to the new ASCO/CAP guideline recommendations. Scoring was done on a 0-3 scale. Strongly positive $(3+)$ was defined as strong complete membranous staining in more than $30 \%$ of the tumor cell population. Weakly positive $(2+)$ was defined as moderate membranous staining in more than $10 \%$ of tumor cells and strong complete membranous staining in less than $30 \%$ of tumor cells. 1+ was defined as either weak or barely perceptible membranous staining in more than $10 \%$ of the tumor cells. 0 was completely negative staining. Scores of 0 and $1+$ were considered as negative for HER2/neu expression, $3+$ as immunopositive, while $2+$ was weakly or borderline positive.

\section{FISH}

FISH analysis was performed to all cases. Amplification of HER-2/neu was evaluated using the Path-Vysion DNA Probe Kit (nodul 35-161060; Vysis) which uses a dual-color probe for determining the number of copies of both HER-2/ neu (orange) and the chromosome 17 centromeres (green). The kit was used following the manufacturers instructions with a few minor modifications. Slides containing 4 micrometerthick paraffin-embedded tissue sections were placed on a slide warmer overnight at $62^{\circ} \mathrm{C}$ followed by deparaffinization 
in Hemo-De, dehydration in $100 \%$ ethanol, and drying on a slide warmer at 45 to $50^{\circ} \mathrm{C}$. Slides were then pretreated with $0,2 \mathrm{~N}$ hydrochloric acid for 22 minutes, followed by washes in purified water and immersion in Vysis wash buffer. They were subsequently immersed in Vysis protease solution at $37^{\circ} \mathrm{C}$ for 40 minutes, washed in Vysis wash buffer, and dried on the slide warmer and $10 \mathrm{ml}$ of probe was applied. Slides are then put in Hybride for 5 minutes at $72^{\circ} \mathrm{C}$. They were then coverslipped, sealed with rubber conent, and placed in a prewarmed humid incubation chamber at $37^{\circ} \mathrm{C}$ for 18 to 22 hours. This was followed by immersion in prewarmed postwash solution at $73^{\circ} \mathrm{C}$ for 4 minutes. The slides were air-dried, and a 4;6 - diamidino -2- phenylindole (DAPI) counterstain was applied.

The scoring system used is described in detail in the manufacturers instructions. In brief, a minimum of 60 nuclei were scored by each of 2 observers using on Olympus BX41 fluorescent microscope with a Chroma filter set (DAPI / spectrum orange / spectrum green triple bandpass) Areas scored were limited to regions of invasive disease as compared with a companion hematoxylin and eosinstained section. The ratio of HER-2/ neu signals (orange) to chromosome 17 centromere signals (green) was determined.

FISH results were than compared to previously stained and evaluated IHC scores to determine how well protein overexpression correlates with gene amplification.

\section{Statistical Analysis}

All statistical analyses were performed with the Statistical Package for the NCSS 2007 version for Windows. The chi-square test and odds ratio were used to examine categorical variables and the association between HER-2/ neu overexpression and other clinicopathological factors in univariate analysis. Logistic regression analysis was used to evaluate HER-2/neu FISH scores. All statistical tests were two-sided and $\mathrm{p}<0.05$ was considered significant.

\section{RESULTS}

The age, nuclear and histologic grade, immunostaining results for ER, PR and HER-2/neu, and FISH results of 100 invasive carcinomas are shown in Table I. Comparison of HER-2/neu immunostaining scores with FISH amplification is shown in Table II. Immunohistochemistry scores showed a good correlation with FISH amplification $(\mathrm{p}<0.0001)$. None of the cases with immune scores at 0 or 1 showed amplification. Four cases (25\%) within 16 cases of score $2+$ (Figure 1) showed amplification, 13 cases (86.7\%) with score $3+$ (Figure 2) were amplified. The association between HER-2/neu amplification and different clinicopathological factors in all patients are presented in Table III. The results indicated a significant correlation between HER-2/neu and grade, but inverse relationship between HER-2/neu and hormone receptors. There is no significant difference in HER-2/neu amplification between women age $\leq 45$ and $>45$ years. The results from the univariate analysis for the association between HER-2/neu amplification and different clinicopathological factors in women aged $\leq 45$ years and $>45$ years are given in Table IV and V, respectively.

In women aged $\leq 45$ years, we found an inverse relationship between HER-2/neu overexpression and progesterone receptor, but we found no association within other factors. However, in women aged $>45$ years, results revealed that ER status, PR status and tumor grade were significantly associated within HER-2/neu amplification.

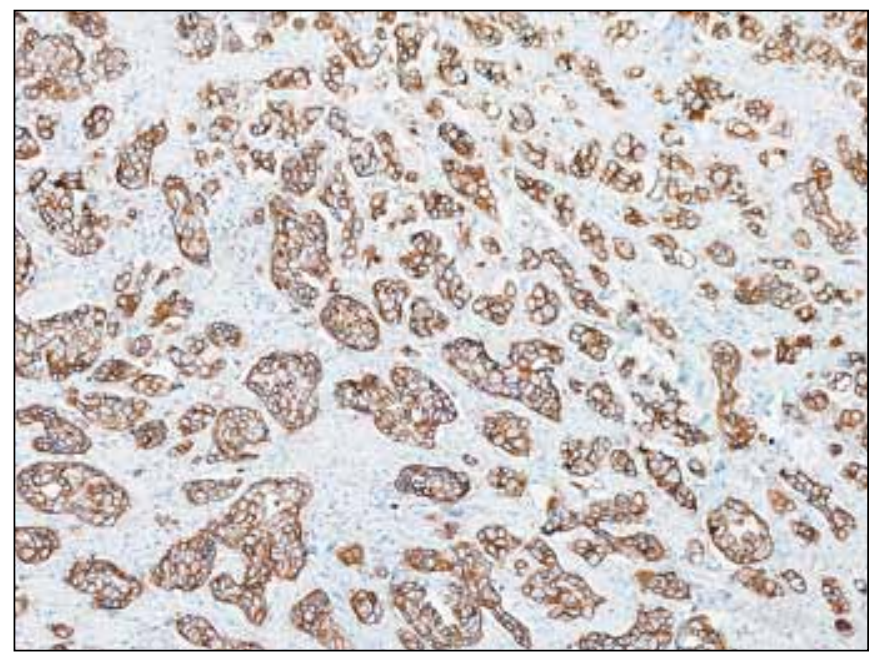

Figure 1: Score 3+ staining (HER-2/neu, x400).

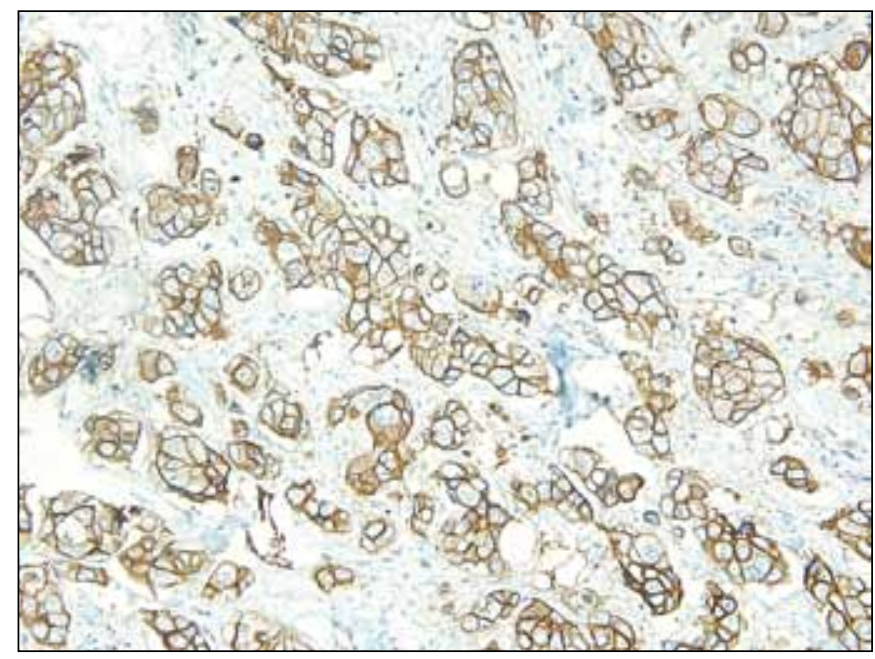

Figure 2: Score 3+ staining (HER-2/neu, x100). 
Table I: Clinicopathological features of 100 invasive mammary carcinomas

\begin{tabular}{|l|c|c|}
\hline \multicolumn{2}{|c|}{} & Number, n(\%) \\
\hline \multirow{3}{*}{ Age } & $<45$ & $32(32)$ \\
\cline { 2 - 3 } & $>45$ & $68(68)$ \\
\hline \multirow{4}{*}{ HER-2/neu Immune Score } & 0 & $52(52)$ \\
\cline { 2 - 3 } & 1 & $17(17)$ \\
\cline { 2 - 3 } & 2 & $16(16)$ \\
\cline { 2 - 3 } & 3 & $15(15)$ \\
\hline \multirow{2}{*}{ HER-2/neu FISH Score } & 0 & $83(83)$ \\
\cline { 2 - 3 } & 1 & $17(17)$ \\
\hline \multirow{3}{*}{ Estrogen Receptor } & 0 & $23(23)$ \\
\cline { 2 - 3 } & 1 & $77(77)$ \\
\hline \multirow{2}{*}{ Progesterone Receptor } & 0 & $20(20)$ \\
\cline { 2 - 3 } & 1 & $80(80)$ \\
\hline \multirow{3}{*}{ Nuclear Grade } & 1 & $8(8)$ \\
\cline { 2 - 3 } & 2 & $48(48)$ \\
\cline { 2 - 3 } Histological Grade & 3 & $44(44)$ \\
\hline & 1 & $13(13,4)$ \\
\cline { 2 - 3 } & 2 & $62(63.9)$ \\
\hline
\end{tabular}

\section{DISCUSSION}

Since the first report by Slamon et al (5) showing that HER$2 /$ neu amplification in breast carcinoma correlates with poor prognosis, accurate detection of the HER-2/neu gene alteration has become increasingly important. Moreover the selection of patients for trastuzumab therapy relies on the presence of this alteration. Given trastuzumab's toxicity (27) accurate determination of HER-2/neu status is crucial.

IHC and FISH are the two FDA-approved methodologies. IHC is by far the most popular and accessible testing modality. It directly detects HER-2/neu protein overexpression and provides very accurate results with advantages including relative ease of performance, rapid turn-around time, and relatively low cost. FISH methodology is quantitatively more precise but also time consuming, technically demanding and more expensive.

FISH methodology theoretically may not be completely concordant with IHC results as it measures HER-2/neu gene amplification and not protein overexpression. HER$2 /$ neu gene amplification occurs in about $15-25 \%$ of breast cancers, where as the interstudy range at HER-2/neu protein overexpression is higher (10-50\%) (28-31). The

Table II: Comparison of HER-2/neu immune scores with FISH amplification $(\mathrm{p}<0.0001)$

\begin{tabular}{|l|c|c|c|c|c|}
\hline \multicolumn{2}{|c|}{} & \multicolumn{4}{|c|}{ HER-2/neu Immune Score } \\
\cline { 3 - 6 } \multicolumn{2}{|c|}{} & $\mathbf{0}(\%)$ & $\mathbf{1}(\%)$ & $\mathbf{2}(\%)$ & $\mathbf{3}(\%)$ \\
\hline \multirow{2}{*}{$\begin{array}{l}\text { HER-2/neu } \\
\text { FISH Score }\end{array}$} & 0 & $52(100)$ & $17(100)$ & $12(75)$ & $2(13.3)$ \\
\cline { 2 - 6 } & 1 & $0(0)$ & $0(0)$ & $4(25)$ & $13(86.7)$ \\
\hline
\end{tabular}

Table III: The association between HER-2/neu amplification and clinicopathological features in all age groups

\begin{tabular}{|l|c|c|c|c|c|c|}
\hline \multicolumn{2}{|c|}{ HER-2/neu FISH Score } & Negative, $\mathbf{n}(\%)$ & Positive, $\mathbf{n}(\%)$ & Total, $\mathbf{n}(\%)$ & $\mathbf{p}$ and $\chi^{\mathbf{2}}$ value & OR 95\% CI \\
\hline \multirow{2}{*}{ Age } & $\leq 45$ & $27(32.5)$ & $5(29.4)$ & $32(32.0)$ & $\chi^{2}: 0.06$ & 0.86 \\
\cline { 2 - 7 } & $>45$ & $56(67.5)$ & $12(70.6)$ & $68(68.0)$ & $\mathrm{p}=0.802$ & $0.27-2.70$ \\
\hline \multirow{3}{*}{ Estrogen Receptor } & Negative & $13(15.7)$ & $10(58.8)$ & $23(23.0)$ & $\chi^{2}: 14.82$ & 7.69 \\
\cline { 2 - 7 } & Positive & $70(84.3)$ & $7(41.2)$ & $77(77.0)$ & $\mathrm{p}=0.0001$ & $2.47-23.8$ \\
\hline \multirow{2}{*}{$\begin{array}{l}\text { Progesterone } \\
\text { Receptor }\end{array}$} & Negative & $11(13.3)$ & $9(52.9)$ & $20(20.0)$ & $\chi^{2}: 13.89$ & 7.36 \\
\cline { 2 - 7 } & Positive & $72(86.7)$ & $8(47.1)$ & $80(80.0)$ & $\mathrm{p}=0.0001$ & $2.34-23.13$ \\
\hline \multirow{3}{*}{ Nuclear Grade } & 1 & $8(9.8)$ & $0(0.0)$ & $8(8.1)$ & & \\
\cline { 2 - 7 } & 2 & $43(52.4)$ & $4(23.5)$ & $47(47.5)$ & $\chi^{2}: 8.87$ & \\
\cline { 2 - 7 } & 3 & $31(37.8)$ & $13(76.5)$ & $44(44.4)$ & $\mathrm{p}=0.012$ & \\
\cline { 2 - 7 } & 1 & $12(14.8)$ & $1(6.7)$ & $13(13.5)$ & & \\
\cline { 2 - 7 } & 2 & $54(66.7)$ & $7(46.7)$ & $61(63.5)$ & $\chi^{2}: 5.79$ & \\
\cline { 2 - 7 }
\end{tabular}


Table IV: Univariate analysis of clinicopathological factors predicting HER-2/neu amplification in women aged $\leq 45$

\begin{tabular}{|l|c|c|c|c|c|c|}
\hline HER-2/neu FISH Score & & Negative, $\mathbf{n}(\%)$ & Positive, $\mathbf{n}(\%)$ & Total, $\mathbf{n}(\%)$ & $\mathbf{p}$ and $\boldsymbol{\chi}^{\mathbf{2}}$ value & OR 95\% CI \\
\hline \multirow{2}{*}{ Estrogen Receptor } & Negative & $4(14.8)$ & $2(40.0)$ & $6(18.8)$ & $\chi^{2}: 1.75$ & 3.83 \\
\cline { 2 - 7 } & Positive & $23(85.2)$ & $3(60.0)$ & $26(81.3)$ & $\mathrm{p}=0.185$ & $0.47-30.7$ \\
\hline \multirow{3}{*}{ Progesterone Receptor } & Negative & $1(3.7)$ & $2(40.0)$ & $3(9.4)$ & $\chi^{2}: 6.54$ & 17.3 \\
\cline { 2 - 7 } & Positive & $26(96.3)$ & $3(60.0)$ & $29(90.6)$ & $\mathrm{p}=0.011$ & $1.18-25.3$ \\
\hline \multirow{3}{*}{ Nuclear Grade } & 1 & $5(18.5)$ & $0(0.0)$ & $5(15.6)$ & & \\
\cline { 2 - 8 } & 2 & $10(37.0)$ & $1(20.0)$ & $11(34.4)$ & $\chi^{2}: 2.34$ & \\
\cline { 2 - 8 } & 3 & $12(44.4)$ & $4(80.0)$ & $16(50.0)$ & $\mathrm{p}=0.309$ & \\
\cline { 2 - 8 } & 1 & $6(23.1)$ & $1(20.0)$ & $7(22.6)$ & & \\
\cline { 2 - 8 } & 2 & $14(53.8)$ & $2(40.0)$ & $16(51.6)$ & $\chi^{2}: 0.63$ & \\
\cline { 2 - 8 } & 3 & $6(23.1)$ & $2(40.0)$ & $8(25.8)$ & $\mathrm{p}=0.727$ & \\
\hline
\end{tabular}

Table V: Univariate analysis of clinicopathologic factors predicting HER- 2/neu amplification in women aged $>45$

\begin{tabular}{|l|c|c|c|c|c|c|}
\hline HER-2/neu FISH Score & & Negative, $\mathbf{n}(\%)$ & Positive, $\mathbf{n}(\%)$ & Total, $\mathbf{n}(\%)$ & $\mathbf{p}$ and $\boldsymbol{\chi}^{\mathbf{2}}$ value & OR 95\% CI \\
\hline \multirow{2}{*}{ Estrogen Receptor } & Negative & $9(16.1)$ & $8(66.7)$ & $17(25.0)$ & $\chi^{2}: 13.49$ & 10.44 \\
\cline { 2 - 7 } & Positive & $47(83.9)$ & $4(33.3)$ & $51(75.0)$ & $\mathrm{p}=0.0001$ & $2.58-42.2$ \\
\hline \multirow{2}{*}{ Progesteron Receptor } & Negative & $10(17.9)$ & $7(58.3)$ & $17(25.0)$ & $\chi^{2}: 8.63$ & 6.44 \\
\cline { 2 - 7 } & Positive & $46(82.1)$ & $5(41.7)$ & $51(75.0)$ & $\mathrm{p}=0.003$ & $1.69-24.5$ \\
\hline \multirow{3}{*}{ Nuclear Grade } & 1 & $3(5.5)$ & $0(0.0)$ & $3(4.5)$ & & \\
\cline { 2 - 8 } & 2 & $33(60.0)$ & $3(25.0)$ & $36(53.7)$ & $\chi^{2}: 6.75$ & \\
\cline { 2 - 8 } & 3 & $19(34.5)$ & $9(75.0)$ & $28(41.8)$ & $\mathrm{p}=0.034$ & \\
\hline \multirow{3}{*}{ Histological Grade } & 1 & $6(10.9)$ & $0(0.0)$ & $6(9.2)$ & & \\
\cline { 2 - 8 } & 2 & $40(72.7)$ & $5(50.0)$ & $45(69.2)$ & $\chi^{2}: 6.16$ & \\
\cline { 2 - 8 } & 3 & $9(16.4)$ & $5(50.0)$ & $14(21.5)$ & $\mathrm{p}=0.046$ & \\
\hline
\end{tabular}

range of HER-2/neu protein overexpression falls to $15-20 \%$ when gene amplification is also present.

In our study, we found good correlation between the IHC and FISH methods $(\mathrm{p}=0.0001)$. None of the cases with score 0 or 1 showed amplification. Twenty five percent of the cases with immune score $2+$ showed amplification. Eighty six percent of the cases with immune score $3+$ were amplified but 2 cases with immune score $3+$ did not show amplification. In the literature, concordance rates between IHC and FISH range from $79 \%$ to $100 \%$ for $3+$ cases $(32,33)$ and between $12 \%$ and $36 \%$ for $2+$ cases $(34,35)$. Although there is good correlation between HER-2/neu gene amplification and protein overexpression, approximately 5-10\% (36) of breast carcinomas overexpress HER-2/neu without amplification and a small undetermined percentage amplify HER-2/neu without overexpression (37). In the study of Rossi et al, the percentage of cases with HER-2/ neu protein overexpression (3+) and FISH negativity rose to $22 \%$ (38). In the literature it is proposed that these $3+$ cases could be due to single copy overexpression of the HER-2/neu gene (39). These cases are considered clinically similar to the immunohistochemically HER-2/neu negative patients (40).

HER-2/neu amplification in different histological types has been a subject of interest. While some prior studies have reported the absence of a significant association between tumor type and HER-2/neu status (40), other studies have shown that HER-2/neu amplification or overexpression was significantly more likely in infiltrating ductal carcinomas than infiltrating lobular carcinomas. But Hoff et.al. (41) demonstrated that infiltrating ductal carcinomas were significantly more likely to show HER-2/neu amplification than infiltrating lobular carcinomas. In this study, 15 of the 17 amplified cases were of the infiltrating ductal carcinoma type and 2 cases were medullary carcinomas. None of the other types was amplified. 
Previous studies have shown a strong correlation between HER-2/neu protein overexpression/amplification and steroid receptor negativity and high tumour grade $(1,4,25,27,42)$. We also found similar results through all age groups. The relationship between the age of patients and HER-2/neu status and other prognostic factors is another subject of interest. We did not find a significant relationship between HER-2/neu gene amplification and patient age as previous studies (1). Although Huang et.al. also did not find a statistically significant difference in expression of HER-2/ neu by age $\leq 45$ and $>45$ years, they suggested an age related association between ER, PR, tumour grade and HER-2/neu overexpression (22). Their results suggested that the inverse association between the hormone receptor and HER-2/ neu status only appeared in women aged beyond 45 but not under 45. In this study, we found inverse relationship between PR and HER-2/neu amplification in all age groups. However, we found a relationship between HER-2/neu status with ER negativity and high tumor grade only in women aged beyond 45 . Konecny et.al. also found that the relatively low levels of HER-2/neu amplification/overexpression were associated with more marked decreases of PR than of ER (43), because PR expression is linked to a biologically active and functional ER (42-44). It has been shown that the activation of growth factor receptors such as HER-2/neu can result in direct phosphorylation and activation of ER in an estrogen-independent manner, which may itself be an important mechanism for tamoxifen resistance in addition to the subsequent reduction in hormone receptor levels (45). However, it appears likely that this reduced expression is not the only mechanism for endocrine resistance in patients with HER-2/neu and that steroid receptors are most likely determined by multiple complex mechanisms, such as phosphorylation of the ER via HER-2/neu activation (46), overexpression of the steroid receptor cofactorA $1 \mathrm{~B} 1$ in HER-2/neu positive tumors (47) and competition between ER and other coregulatory receptor proteins resulting in altered HER-2/neu expression (48).

In our institution, we perform immunohistochemistry for detecting HER-2/neu and hormonal status. In this study, we compared our IHC scores with FISH method and found a significant correlation. In conclusion, we suggest performing FISH only in cases with an IHC score of 2+. Although we have a limited number of patients, we found that mainly PR negativity predicts HER-2/neu overexpression through all age groups. In women beyond the age of 45 , there is also a strong correlation between HER-2/neu, ER negativity and tumor grade. A combination of HER-2/neu and histological prognostic factors can help to determine subgroups for more specific treatment protocols.

\section{REFERENCES}

1. Pinto AE, André S, Pereira T, Nóbrega S, Soares J: C-erbB-2 oncoprotein overexpression identifies a subgroup of estrogen receptor positive $(\mathrm{ER}+)$ breast cancer patients with poor prognosis. Ann Oncol 2001, 12:525-533

2. Huang HJ, Neven P, Drijkoningen M, Paridaens $R$, Wildiers H, Van Limbergen E, Berteloot P, Amant F, Christiaens MR, Vergote I: Association between HER-2 /neu and the progesterone receptor in oestrogen-dependent breast cancer is age-related. Breast Cancer Res Treat 2005, 91:81-87

3. Ross JS, Fletcher JA: The HER-2 /neu oncogene in breast cancer: Prognostic factor, predictive factor, and target for therapy. Oncologist 1998, 3:237-252

4. Révillion F, Bonneterre J, Peyrat JP: ERBB2 Oncogene in human breast cancer and its clinical significance. Eur J Cancer 1998, 34:791-808

5. Slamon DJ, Clark GM, Wong SG, Lewin WJ, Ullrich A, McGuire WL: Human breast cancer: Correlation of relapse and survival with amplification of the HER 2/ neu oncogene. Science 1987, 235:177-182

6. Tandon AK, Clark GM, Chamness GC, Ullrich A, McGuire WL: HER-2 /neu oncogene protein and prognosis in breast cancer. J Clin Oncol 1989, 7:1120-1128

7. Sjögren S, Inganäs M, Lindgren A, Holmberg L, Bergh J: Prognostic and predictive value of c-erb-B2 overexpression in primary breast cancer, alone and in combination with other prognostic markers. J Clin Oncol 1998, 16:462-469

8. Muss HB, Thor AD, Berry DA, Kute T, Liu ET, Cirrincione CT, Budman DR, Wood WC, Barcos M, Henderson IC: C-erb-B2 expression and response to adjuvant therapy in women with node-positive early breast cancer. N Engl J Med 1994, 330: 1260-1266

9. Cobleigh MA, Vogel CL, Tripathy D, Robert NJ, Scholl S, Fehrenbacher L, Wolter JM, Paton V, Shak S, Lieberman G, Slamon DJ: Multinational study of the efficacy and safety of humanized anti-HER2 overexpressing metastatic breast cancer that has progressed after chemotherapy for metastatic disease. J Clin Oncol 1999, 17:2639-2648

10. Slamon DJ, Leyland-Jones B, Shak S, Fucks H, Paton V, Bajamonde A, Fleming T, Eiermann W, Wolter J, Pegram M, Baselga J, Norton L: Use of chemotherapy plus a monoclonal antibody against HER2 for metastatic breast cancer that overexpresses HER2. N Engl J Med 2001, 344:783-792

11. Hudziak RM, Lewis GD, Winget M, Fendly BM, Shepard HM, Ullrich A: p185HER2 monoclonal antibody has antiproliferative effects in vitro and sensitizes human breast tumours cells to tumor necrosis factor. Mol Cell Biol 1989, 9:1165-1172

12. Wolff AC, Hammond ME, Schwartz JN, Hagerty KL, Allred DC, Cote RJ, Dowsett M, Fitzgibbons PL, Hana WM, Langer A, McShane LM, Paik S, Pegram MD, Perez EA, Pres MF, Rhodes A, Sturgeon C, Taube SE, Tubbs R, Vance GH, van de Vijver M, Wheeler TM, Hayes DF: American Society of Clinical Oncology / College of American Pathologist guideline recommendations for human epidermal growth factor receptor 2 testing in breast cancer. J Clin Oncol 2007, 25:118-145 
13. Cardoso F, Durbecq V, Larsimont D, Paesmans M, Leroy JY, Rovas G, Sotiriou C, Renald N, Richard V, Piccart MJ, Di Leo A: Correlation between complete response to anthracycline-based chemotherapy and topoisomerase II-alpha gene amplification and protein overexpression in locally advanced / metastatic breast cancer. Int J Oncol 2004, 24:201-209

14. Joensuu H, Kellokumpu-Lehtinen PL, Bono P, Alanko T, Kataja $V$, Asola R, Utriainen T, Kokko R, Hemminki A, Tarkkanen M, Turpeenniemi-Hujanen T, Jyrkkiö S, Flander M, Helle L, Ingalsuo S, Johansson K, Jääskeläinen AS, Pajunen M, Rauhala M, Kaleva-Kerola J, Salminen T, Leinonen M, Elomaa I, Isola J: Adjuvant docetaxel or vinorelbine with or without trastuzumab for breast cancer. N Engl J Med 2006, 354:809-820

15. Romond EH, Perez EA, Bryant J, Suman VJ, Geyer CE Jr, Davidson NE, Tan-Chiu E, Martino S, Paik S, Kaufman PA, Swain SM, Pisansky TM, Fehrenbacher L, Kutteh LA, Vogel VG, Visscher DW, Yothers G, Jenkins RB, Brown AM, Dakhil SR, Mamounas EP, Lingle WL, Klein PM, Ingle JN, Wolmark $N$ : Trastuzumab plus adjuvant chemotherapy for operable HER2positive breast cancer. N Engl J Med 2005, 353:1673-1684

16. Hayes DF, Picard MH: Heart of Darkness: The downside of trastuzumab. J Clin Oncol 2006, 24: 4056-4058

17. Slamon DJ, Godolphin W, Jones LA, Holt JA, Wong SG, Keith DE, Lewin WJ, Stuart SG, Udove J, Ullrich A, Press MF: Studies of the HER-2/neu proto-oncogene in human breast and ovarian cancer. Science 1989, 244:707-712

18. Yaziji H, Goldstein LC, Barry TS, Werling R, Hwang H, Ellis GK, Gralow JR, Livingston RB, Gown AM: HER-2 testing in breast cancer using paralel tissue-based methods. JAMA 2004, 291:1972-1977

19. Owens MA, Horten BC, Da Silva MM: HER2 amplification ratios by fluorescence in situ hybridization and correlation with immunohistochemistry in a cohort of 6556 breast cancer tissues. Clin Breast Cancer 2004, 5:63-69

20. Dowsett M, Hanna WM, Kockx M, Penault-Llorca F, Rüschoff J, Gutjahr T, Habben K, van de Vijver MJ: Standardization of HER2 testing: Results of an international proficiency-testing ring study. Mod Pathol 2007, 20, 584-591

21. Albain KS, Allred DC, Clark GM: Breast cancer outcome and predictors of outcome: are there age differentials? J Natl Cancer Inst Monogr 1994, 16:35-42

22. Russell KS, Hung MC: Transcriptional repression of the neu proto-oncogene by estrogen stimulated estrogen receptor. Cancer Res 1992, 52:6624-6629

23. Huang HJ, Neven P, Drijkoningen M, Paridaens $R$, Wildiers $H$, Van Limbergen E, Berteloot P, Amant F, Vergote I, Christiaens MR: Hormone receptors do not predict the HER2 / neu status in all age groups of women with an operable breast cancer. Ann Oncol 2005, 16:1755-1761

24. Nixon AJ, Neuberg D, Hayes DF, Gelman R, Connolly JL, Schnitt $S$, Abner A, Recht A, Vicini F, Harris JR: Relationship of patient age to pathologic features of the tumor and prognosis for patients with stage I or II breast cancer. J Clin Oncol 1994, 12:888-894

25. Remvikos Y, Magdelenat H, Dutrillaux B: Genetic evolution of breast cancers. III: age-dependent variations in the correlations between biological indicators of prognosis. Breast Cancer Res Treat 1995, 34:25-33
26. Greene FL, Page DL, Fleming ID, Fritz AG, Balch CM, Haller DG, Morrow M. (Eds): American Joint Committee on Cancer Staging Manual. 6th ed., New York, Springer-Verlag, 2002, 223240

27. Sparano JA: Cardiac toxicity of trastuzumab (Herceptin): Implications for the design of adjuvant trials. Semin Oncol 2001, 28: $20-27$

28. Pala EE, Zekioğlu O, Özdemir N, Yılmaz R, Kapkaç M: Comparison of immunohistochemistry and fluorescence in situ hybridisation for the analysis of HER2/neu and topoisomerase II-alpha status in human breast cancer. Turk Patoloji Derg 2010, 26:222-229

29. Ferrero-Poüs M, Hacène K, Bouchet C, Le Doussal V, TubianaHulin M, Spyratos F: Relationship between c-erbB-2 and other tumor characteristics in breast cancer prognosis. Clin Cancer Res 2000, 6:4745-4754

30. Ridolfi RL, Jamehdor MR, Arber JM: HER-2 /neu testing in breast carcinoma: A combined immunohistochemical and fluorescence in situ hybridization approach. Mod Path 2000, 13:866-873

31. Hana W, Kahn HJ, Trudeau M: Evaluation of HER-2/neu (erbB2) status in breast cancer: from bench to bedside. Mod Pathol 1999, 12:827-834

32. Lebeau A, Deimling D, Kaltz C, Sendelhofert A, Iff A, Luthardt B, Untch M, Löhrs U: HER-2 /neu analysis in archival tissue samples of human breast cancer: Comparison of immunohistochemistry and fluorescence in situ hybridization. J Clin Oncol 2001, 19: 354-363

33. Tubbs RR, Pettay JD, Roche PC, Stoler MH, Jenkins RB, Grogan TM: Discrepancies in clinical laboratory testing of eligibility for trastuzumab therapy: Apparent immunohistochemical falsepositives do not get the message. J Clin Oncol 2001, 19:2714-2721

34. Perez EA, Roche PC, Jenkins RB, Reynolds CA, Halling KC, Ingle JN, Wold LE: HER-2/neu testing in patients with breast cancer: Poor correlation between weak positivity and gene amplification by fluorescence in situ hybridization. Mayo Clinic Proc 2002, 77:148-154

35. Ridolfi RL, Jamehdor MR, Arber JM: HER-2 / neu testing in breast carcinoma: A combined immunohistochemical and fluorescence in situ hybridization approach. Mod Pathol 2000,13:866-873

36. Birner P, Oberhuber G, Stani J, Reithofer C, Samonigg H, Hausmaninger H, Kubista E, Kwasny W, Kandioler-Eckersberger D, Gnant M, Jakesz R: Evaluation of the United States Food and Drug Administration-approved scoring and test system of HER2 protein expression in breast cancer. Clin Cancer Res 2001, 7:1669-1675

37. Pauletti G, Godolphin W, Press MF, Slamon DJ: Detection and quantitation of HER-2 / neu gene amplification in human breast cancer archival material using fluorescence in situ hybridization. Oncogene 1996, 13:63-72

38. Rossi E, Ubiali A, Cadei M, Balzarini P, Valagussa E, Lucini L, Alpi F, Galletti A, Fontana L, Tedoldi C, Grigolato P: HER-2 / neu in breast cancer: A comparative study between histology, immunohistochemistry, and moleculer technique (FISH). Appl Immunohistochem Mol Morphol 2006, 14:127-131 
39. Uehara T, Kaneko Y, Kanda N, Yamamoto T, Higashi Y, Nomoto C, Izumo T, Takayama S, Sakurai M: C-erb-B2 and c-erbA1(ear-1) gene amplification and c-erb-2 protein expression in Japanese breast cancers: their relationship to the histology and other disease parameters. Jpn J Cancer Res 1990, 81:620-624

40. Persons DL, Borelli KA, Hsu PH: Quantitation of HER-2 / neu and c-myc gene amplification in breast carcinoma using fluorescence in situ hybridization. Mod Pathol 1997, 10: 720-727

41. Hoff ER, Tubbs RR, Myles JL, Procop GW: HER-2 / neu amplification in breast cancer: stratification by tumor type and grade. Am J Clin Pathol 2002, 117:916-921

42. Moriki T, Takahashi T, Hiroi M, Yamane T, Hara H: Histological grade in invasive ductal carcinoma of breast correlates with the proliferative activity evaluated by BrdU: an immunohistochemical study including correlations with p53, c-erbB-2 and estrogen receptor status. Pathol Int 1996, 46:417-425

43. Konecny G, Pauletti G, Pegram M, Untch M, Dandekar S, Aguilar Z, Wilson C, Rong HM, Bauerfeind I, Felber M, Wang HJ, Beryt M, Seshadri R, Hepp H, Slamon DJ: Quantitative association between HER-2/neu and steroid hormone receptors in hormone receptor-positive primary breast primary breast cancer. J Natl Cancer Inst 2003, 95:142-153
44. Fuqua SA, Fitzgerald SD, Chamness GC, Tandon AK, McDonnell DP, Nawaz Z, O'Malley BW, McGuire WL: Variant human breast tumor estrogen receptor with constituve transcriptional activity. Cancer Res 1991, 51:105-109

45. Kolár Z, Murray PG, Zapletalová J: Expression of C-erb-B2 in node negative breast cancer does not correlate with estrogen receptor status, predictors of hormone responsiveness, or PCNA expression. Neoplasma 2002, 49:110-113

46. Smith CL: Cross-talk between peptide growth factor and estrogen receptor signaling pathways. Biol Reprod 1998, 58:627-632

47. Bouras T, Southey MC, Venter DJ: Overexpression of the steroid receptor coactivator AIB1 in breast cancer correlates with the absence of estrogen and progesterone receptors and positivity for p53 and HER-2 /neu. Cancer Res 2001, 61:903-907

48. Newman SP, Bates NP, Vernimmen D, Parker MG, Hurst HC: Cofactor competition between the ligand-bound oestrogen receptor end an intron 1 enhancer leads to oestrogen repression of ERBB2 expression in breast cancer. Oncogene 2000, 19: 490-497 